\title{
Information about sun exposure, protection, awareness and behavioural patterns of medical students in Kolar
} Kolar'da tıp öğrencilerinin güneș maruziyeti, korunma, farkındalık ve davranıș kalıpları hakkındaki bilgisi

๑ Shruthi Madhavi Govindarajulu, ๑ Rajashekar Talari Srinivas, ๑ Suresh Kumar Kuppuswamy,
๑ Priya Prem

Sri. Devaraj Urs Medical College, Departmen of Dermatology, Kolar, India

\begin{abstract}
Background and Design: The harmful ultraviolet radiation of sunlight can damage skin cells and affect the skin's normal appearance. The short term effects associated with sun exposure include acute skin damage associated changes such as sunburn, suntan and the long term effects are delayed pigmentation, impaired vitamin D synthesis, altered immunological responses of the skin, photodamage and photocarcinogenesis. The majority of these photodermatoses are preventable with the implementation of appropriate sun protection measures and behavioral changes.

Materials and Methods: Data collection was done with the help of a structured questionnaire which was distributed among 339 undergraduate medical students in their $4^{\text {th }}, 7^{\text {th }}, 8^{\text {th }}$ and $9^{\text {th }}$ term attending dermatology postings at a medical college attached to a tertiary hospital from January 2018 to July 2018.

Results: The majority of the students in this study were $4^{\text {th }}$ term undergraduates representing $35.3 \%$ of the population. The mean \pm standard deviation scores of knowledge, behaviour and awareness were $11.67 \pm 3.31,12.32 \pm 5.004,24 \pm 6.282$, respectively. Only $26.8 \%$ of the above population always used sunscreen during daily activities, $32.1 \%$ sometimes, $25.6 \%$ rarely used and $15.3 \%$ never used sunscreen during daily activities. One-Way ANOVA tests depicted a statistically significant difference among the various term students with respect to variables of knowledge, behaviour and awareness score with a $p<0.001$

Conclusion: The results of this study indicate that knowledge regarding sun exposure and its adverse effects, behaviour and awareness even among medical students to sun protection is inadequate. Sun protection should start at an early age and therefore awareness campaigns are highly recommended.
\end{abstract}

Keywords: Photodermatoses, sunscreen, photocarcinogenesis

Öz

Amaç: Güneş ışı̆ııın zararlı ultraviyole radyasyonları deri hücrelerine zarar verebilir, derinin normal görünümünü etkiler. Güneşe maruz kalmanın kısa vadeli etkileri güneş yanığı, bronzlaşma gibi akut deri hasarı ile ilişkili değişiklikleri içerir, uzun vadeli etkiler ise gecikmiş pigmentasyon, bozulmuş D vitamini sentezi, derinin değişmiş immünolojik tepkileri, fotohasar ve fotokarsinogenezdir. Bu fotodermatozların birçoğu, uygun güneş koruma önlemlerinin ve davranışsal değişikliklerin uygulanması ile önlenebilir.

Gereç ve Yöntem: Veri toplama, Ocak 2018'den Temmuz 2018'e kadar üçüncü basamak bir hastaneye bağlı bir tıp fakültesinde dermatoloji görevlerine devam eden 4., 7., 8. ve 9. dönemlerde 339 tıp fakültesi öğrencisi arasında dağıtılan yapılandırımış bir anket yardımıyla yapıldı. Bulgular: Bu çalışmadaki öğrencilerin çoğunluğu katılımcıların \%35,3'ünü temsil eden 4. dönem mezunlarıydı. Bilgi, davranış ve farkındalık skoru için ortalama \pm standart sapma değerleri sırasıyla $11,67 \pm 3,31,12,32 \pm 5,004,24 \pm 6,282$ idi. Yukarıdaki popülasyonun sadece $\% 26,8$ 'i günlük aktiviteler sırasında her zaman güneş kremi kullanıyordu, \%32,1'i bazen, \%25,6'sı nadiren güneş kremi kullanırken, \%15,3'ü günlük

Address for Correspondence/Yazışma Adresi: Rajashekar Talari Srinivas MD, Sri. Devaraj Urs Medical College, Departmen of Dermatology, Kolar, India Phone: +08025289313 E-mail: shruthi.231@gmail.com Received/Geliş Tarihi: 22.10.2019 Accepted/Kabul Tarihi: 06.05.2020 ORCID: orcid.org/0000-0003-3796-2812

CCopyright 2020 by Turkish Society of Dermatology and Venereology

Turkderm - Turkish Archives of Dermatology and Venereology published by Galenos Yayınevi. 
aktiviteler sırasında hiç güneş kremi kullanmıyordu. One-Way ANOVA testleri farklı dönem öğrencileri arasında bilgi, davranış ve farkındalık değişkenlerinin puanları açısından $p<0,001$ olan istatistiksel olarak anlamlı bir fark olduğunu ortaya koydu.

Sonuç: Bu çalışmanın sonuçları, güneşe maruz kalma ve güneşin yan etkileri, davranışlar ve farkındalığın tıp öğrencileri arasında bile güneşten korunma konusundaki bilginin yetersiz olduğunu göstermektedir. Güneşten korunma erken yaşta başlamalıdır ve bu nedenle bilinçlendirme kampanyaları şiddetle tavsiye edilir.

Anahtar Kelimeler: Fotodermatozlar, güneş kremi, fotokarsinogenez

\section{Introduction}

Ultraviolet (UV) radiation alters the proliferation, differentiation and survival of several different cell types and thereby affects skin homeostasis. The most abundant form of UV radiation that reaches the earth's surface is ultraviolet A (UVA) and only a small amount of UVB radiation reaches the earth's surface. In recent years, a rapid depletion in the ozone layer has resulted in a major quantity of UVB rays reaching the earth's surface and this has had a global impact and increased the risk of mutagenesis and photo-carcinogenesis. The extent of ozone loss in the southern hemisphere is more than the northern hemisphere with increased negative impact of UV radiation on this population?.

The harmful effects of UV rays on the skin can be acute or chronic. The acute effects are damage to DNA, apoptosis, erythema, immunosuppression and increased risk of pigmentation due to stimulation of melanogenesis. The chronic effects include photoaging and photocarcinogenesis. The malignancies that occur are basal cell carcinoma and squamous cell carcinoma. The risk of occurrence of basal cell carcinoma to squamous cell carcinoma is 4:1. Non-melanoma skin cancers have a lower risk of mortality and morbidity but cause a profound impairment in patient's social life and daily activities. The most lethal tumor of all of these is malignant melanoma. The survival rates of these tumors have increased with the recent advances in diagnostic technology and therapeutics, however, the risk of mortality still continues to rise, emphasising the need of early detection and patient education'.

The highest UVB radiation is found near the equator. India lies in the tropical belt and the population here is exposed to a high degree of both UVA and UVB radiation?

The adverse effects that occur with sun exposure can be prevented with appropriate sun protective measures. The measures for effective sun protection are avoidance of sun exposure between 10.00 a.m. and 2.00 p.m, using sunscreen, seeking shade, avoiding tanning beds minimizing sunburns, and wearing wide-brimmed hats, protective clothing, and sunglasses ${ }^{3}$.

Sunscreens constitute the main backbone of sun protection. They act by reflecting, absorbing, or dispersing the UV radiation and reducing its transmission into the skin ${ }^{3}$.

Sunscreens were approved by Food and Drug Administration to prevent sunburn, aging, carcinoma and sunlight induced pigmentation². Patients have to be educated about sunscreen use and its benefits in skin protection ${ }^{3}$.

The cost of sunscreens and the greasy formulations in which they are available are the major reason for discontinuation of sunscreen in individuals. The alternative formulations of sunscreens that are available including less greasy formulations like gels, sprays, and lip balms are unknown to many and even to some medical professionals ${ }^{4}$.

Though many studies have been conducted worldwide to assess the sun protective behaviour and use of sunscreens. In India very few such studies have been done. This is the second study of its kind ${ }^{3}$.
Although a number of international surveys regarding skin cancer, prevention and control programmes have been successful in raising public consciousness, these programmes do not assess their behavioural implementation. In daily practice, even medical students as well as the local population are unaware of proper sun protection practices ${ }^{3}$.

This study was undertaken on medical students in India who constitute the top layer of the educational society and also who are the future of propagation of education in the country as practitioners and teachers. This is the first study of such kind in India to be conducted on this group of participants.

\section{Materials and Methods}

\section{Study design}

A cross-sectional questionnaire-based study was conducted. The Sri. Devaraj Urs Medical College Institutional Ethics Committee approval was obtained (approval number: SDUM/KLR/IEC/94.2018-19, date: 23.05.2018). Informed consent was taken and 339 undergraduates attending the dermatology postings from June to November at R.L Jalappa Hospital, Kolar were included in the study and answered the questionnaire containing questions to assess the knowledge, attitude, and behaviour questions regarding sun exposure and skin protection practices.

\section{Data collection}

The paper copies with the list of 35 questionnaire were distributed to undergraduate medical students.

\section{Devices/tools}

A questionnaire was formed based on previous studies and in accordance with the circumstances of the current sample population. A 35-question final questionnaire based on multiple choice and self-report instrument and Likert scale was developed ${ }^{46}$. The assessment was done based on three domains, the first assessment was based on the seven questions that focused on socio-demographic characteristics like age, gender, marital status, nationality and history of sunburn ${ }^{6}$. The second domain comprised of ten questions about sun protective behaviours, and the third set comprised of eighteen questions about the sun and its hazards, sun protective measures and sunscreen application ${ }^{6}$. The questionnaire took an approximate time of ten minutes per student.

\section{Behaviour score}

The behaviour was calculated as follows with "sometimes" assigned a score of two, "rarely" equivalent to a count of one and "never" allocated as zero. The behaviour score was calculated with the least score of zero and a highest score of 24 . The behaviour score was obtained as per Likert scale and individuals with variable answers were not included in the study. 


\section{Knowledge level score}

The hazardous outcomes of sun exposure such as malignancy and the protective measures against the sun were assessed with 18 questions. The score of knowledge level (KLS) was calculated by giving one point to each correct answer (zero points were allotted to "False/I do not know" answers). The scores were summed together ranging from 0 (minimum score) to 18 (maximum score).

\section{Awareness score}

The total awareness score was calculated by adding the KLS and behaviour score. The total score was calculated as 42 .

\section{Statistical Analysis}

The sample size for the study was calculated based on the average awareness score which was obtained from a study conducted on medical students on their knowledge, awareness and behaviour about skin cancer, the hazards of sun exposure and utilization of sunscreen ${ }^{7}$. The estimated average variance was found to be 49 with a $99 \%$ confidence interval $(\mathrm{Cl})$ with an alpha error of $1 \%$ the required sample size found to be 339. A chi-square test was performed to assess the link between the KLS, behaviour score, and demographic details.

\section{Analysis and statistical method}

Collected data was coded into excel format on quantitative measures and presented by mean standard deviation and $\mathrm{Cl}$ on categorical data by proportions. One-Way ANOVA was used to compare the mean scores in different groups. Multiple linear regression was used and chi-square test was done to compare the different proportions. Any p-value less than 0.5 was considered statistically significant.

\section{Results}

The study was conducted to assess the knowledge, behaviour and awareness of undergraduate medical students towards sun exposure and sun protection practices. In our study, the maximum study participants were males 180 (53.1\%) followed by females 159 (46.9\%). The number of students in this study were $4^{\text {th }}$ term $(35.3 \%), 7^{\text {th }}$ term (29.4\%), $9^{\text {th }}$ term $(24.7 \%)$ and $8^{\text {th }}$ term $(10.3 \%)$ (Table 1$)$.

\section{Knowledge level}

The accurate answers were in the range of $23 \%$ to $84.9 \%$ with minimum knowledge on the question "with the proper application of SPF-30 one can stay in the sun 30 minutes longer without sustaining sun burns" (23\%) to maximum knowledge on the question "periodic examination by a dermatologist helps in detection of early stages of skin cancers" (84.9\%) (Table 2).

\section{Behaviour}

The behaviour related variables were assessed and it was found that $25 \%$ of study population avoided sun or preferred shade during the peek hours and $53 \%$ of the population avoided sun sometimes only. The study population comprised of $10.9 \%$ of students always practicing outdoors; $56.9 \%$ of students sometimes practicing outdoors; and $11.7 \%$ of students never practicing outdoors during the day. Further, it was observed that $48.9 \%$ of population never used tanning beds and only $7.3 \%$ of population used tanning beds indicating its uncommon practice among individuals. In the study population $32.4 \%$ used sunscreen during daily activities, and $15.3 \%$ of the subjects never used

\begin{tabular}{|c|c|c|}
\hline Characteristics & $\mathbf{n}$ & $\%$ \\
\hline \multicolumn{3}{|l|}{ 1. Age } \\
\hline$<25$ & 339 & 100 \\
\hline \multicolumn{3}{|l|}{ 2. Marital status } \\
\hline Married & 10 & 2.9 \\
\hline Unmarried & 329 & 97 \\
\hline \multicolumn{3}{|l|}{ 3. Nationality } \\
\hline Indian & 339 & 100 \\
\hline \multicolumn{3}{|l|}{ 4. Gender } \\
\hline Male & 180 & 53.1 \\
\hline Female & 159 & 46.9 \\
\hline \multicolumn{3}{|l|}{ 5. Term } \\
\hline $4^{\text {th }}$ & 120 & 35.3 \\
\hline $7^{\text {th }}$ & 100 & 29.4 \\
\hline $8^{\text {th }}$ & 35 & 10.3 \\
\hline $9^{\text {th }}$ & 84 & 24.7 \\
\hline \multicolumn{3}{|c|}{ 6. "Have you ever had sunburn under the age of 15 ?" } \\
\hline No & 307 & 90.5 \\
\hline Yes & 32 & 9.4 \\
\hline \multicolumn{3}{|c|}{ 7. "Have you ever had a late sunburn?" } \\
\hline No & 289 & 85 \\
\hline Yes & 50 & 14.7 \\
\hline
\end{tabular}

sunscreens during daily activities. Among the sunscreen users $35.1 \%$ used sunscreen of SPF-30 and above. The practice of sunscreen use while sun bathing on holidays was seen in $32.4 \%$ of study population and $31.2 \%$ of them did not use sunscreen even while sunbathing on holidays. The other protective measures such as sunglasses were used by $26.2 \%$, followed by protective clothing in $25.6 \%$ of the individuals and hats in $16.2 \%$ of them. The rest of these individuals $(31.8 \%)$ also failed to use other sun protective measures. Majority of the study population (40.7\%) failed to get their skin checked by physicians for potential cancerous lesions and only few of them (12\%) got their skin examined for potential cancerous lesions. Self-examination of skin for precancerous skin lesions was occasionally performed by $30.9 \%$ of these individuals and never performed by $30 \%$ of the population. The reasons for not using sun protective measures were investigated, and the most common reasons were laziness in $54.6 \%$ individuals, followed by willingness to tan in $13.9 \%$, embarrassment in $8.5 \%$, and the thought that these measures would not be necessary in $23 \%$. Only $15 \%$ of these individuals have recently suffered from sunburns. A total of $9.4 \%$ of these individuals recently suffered from sunburn before the age of fifteen (Table 3).

\section{Knowledge and behaviour}

The knowledge and behaviour score together constituted the awareness score. The mean knowledge, behaviour and awareness score and total knowledge, behaviour and awareness score have been calculated according to term and is as provided in the table. A statistically significant difference in mean awareness score was seen 
Table 2. Knowledge related questionnaire and responses of the participants $(n=339)$

Variables

\begin{tabular}{l|l}
$\mathbf{n}$ & $\%$ \\
\hline
\end{tabular}

1. "Using sunscreen protects the skin from cancer."

True

False

\begin{tabular}{|l|l|}
\hline 214 & 63.1 \\
\hline 60 & 17.6 \\
\hline 65 & 18.2 \\
\hline
\end{tabular}

No idea

2. "Periodic examination by a dermatologist helps in detection of early stages of skin cancers."

\begin{tabular}{|l|l|l|}
\hline True & 288 & 84.9 \\
\hline False & 25 & 7.3 \\
\hline No idea & 26 & 7.6 \\
\hline
\end{tabular}

3. "Early stages of skin cancer can be detected by selfexamination of suspicious lesions."

\begin{tabular}{|l|l|l|}
\hline True & 325 & 78.5 \\
\hline False & 28 & 6.8 \\
\hline No idea & 61 & 14.7 \\
\hline
\end{tabular}

4. "Freckles are caused by excessive sun exposure."

\begin{tabular}{|l|l|l|}
\hline True & 214 & 63.1 \\
\hline False & 50 & 14.7 \\
\hline No idea & 79 & 23.3 \\
\hline
\end{tabular}

5. "Excessive sun exposure causes premature skin wrinkles."

\begin{tabular}{|l|l|l|}
\hline True & 204 & 60.2 \\
\hline False & 82 & 7.7 \\
\hline No idea & 73 & 28.3 \\
\hline
\end{tabular}

6. "Excessive sun exposure causes skin cancer."

\begin{tabular}{|l|l|l|}
\hline True & 198 & 58.4 \\
\hline False & 68 & 20 \\
\hline No idea & 73 & 21.5 \\
\hline
\end{tabular}

7. "The most harmful effect of sun exposure is seen between 10:00 a.m. to 2:00 p.m."

\begin{tabular}{|l|l|l|}
\hline True & 229 & 67.5 \\
\hline False & 50 & 14.7 \\
\hline No idea & 60 & 17.6 \\
\hline
\end{tabular}

8. "A sunscreen with an SPF (sun protection factor) of at least 30 is considered ideal."

\begin{tabular}{|l|l|l|}
\hline True & 203 & 59.8 \\
\hline False & 44 & 13 \\
\hline No idea & 92 & 27.1 \\
\hline
\end{tabular}

9. "SPF of more than $\mathbf{3 0}$ offers slightly greater protection with a drawback of higher cost."

\begin{tabular}{|l|l|l|}
\hline True & 137 & 40.4 \\
\hline False & 66 & 19.4 \\
\hline No idea & 136 & 40.1 \\
\hline
\end{tabular}

10. "If you want to apply for whole body a minimum of $30 \mathrm{~mL}$ or $\mathbf{2}$ table spoon of sunscreen is required."

\begin{tabular}{|l|l|l|}
\hline True & 179 & 52.8 \\
\hline False & 70 & 20.6 \\
\hline No idea & 100 & 29.4 \\
\hline
\end{tabular}

Table 2 continued

11. "With the proper application of SPF 30 one can stay in the sun $\mathbf{3 0}$ minutes longer without sustaining sun burns."

\begin{tabular}{|l|l|l|}
\hline True & 78 & 23 \\
\hline False & 129 & 38 \\
\hline No idea & 132 & 39 \\
\hline
\end{tabular}

12. "One fingertip is equal to the amount of cream/lotion that covers both sides of a hand when applied."

\begin{tabular}{|l|l|l|}
\hline True & 192 & 56.6 \\
\hline False & 76 & 22.4 \\
\hline No idea & 71 & 20.9 \\
\hline
\end{tabular}

13. "Wet clothing means more transmission of UV rays and more damage."

\begin{tabular}{|l|l|l|}
\hline True & 162 & 47.7 \\
\hline False & 80 & 23.5 \\
\hline No idea & 97 & 28.6 \\
\hline
\end{tabular}

14. "Sunscreen application should be done 15-30 minutes before exposure to the sun with re-application every 2 hours."

\begin{tabular}{|l|l|l|}
\hline True & 210 & 61.9 \\
\hline False & 62 & 18.2 \\
\hline No idea & 67 & 19.8 \\
\hline
\end{tabular}

15. "Blonde hair or red hair poses a greater risk of skin cancer."

\begin{tabular}{|l|l|l|}
\hline True & 172 & 50.7 \\
\hline False & 52 & 15.3 \\
\hline No idea & 115 & 33.9 \\
\hline
\end{tabular}

16. "The risk of skin cancer varies with skin type."

\begin{tabular}{|l|l|l|}
\hline True & 218 & 64.3 \\
\hline False & 38 & 11.2 \\
\hline No idea & 83 & 24.5 \\
\hline
\end{tabular}

17. "Chances of melanoma later in life doubles with one blistering sunburn during childhood."

\begin{tabular}{|l|c|c|}
\hline True & 172 & 50.7 \\
\hline False & 63 & 18.5 \\
\hline No idea & 104 & 30.6 \\
\hline
\end{tabular}

18. "Does a family history of skin cancer further increase the individual's risk of skin cancer?"

\begin{tabular}{|l|l|l|}
\hline True & 232 & 68.4 \\
\hline False & 46 & 13.5 \\
\hline No idea & 61 & 17.9 \\
\hline SPF: Sun protection factor, UV: Ultraviolet & \\
\hline
\end{tabular}

between the male and female participants of the study $(p=0.0138)$. One-Way ANOVA test revealed statistically significant difference among individuals in different terms $(p<0.001)$ with respect to knowledge, awareness and behaviour variables. Multiple linear regression showed that the term is a significant predictor of behavior score $(\beta=0.371$, $p=0.025$ ) with an overall model fit $R^{2}=0.022$ and a significant predictor of knowledge score $(\beta=0.473, p=0.005)$ with an overall model fit $\mathrm{R}^{2}=0.023$ (Table 4). 
Table 3. Behaviour related questionnaire and responses of the participants $(n=339)$

Behaviour related variables

n (\%)

1. "How frequently do you forego sun exposure or seek protection during the peak hours?"

\begin{tabular}{|l|l|}
\hline Always & 25.1 \\
\hline Sometimes & 53.3 \\
\hline Rarely & 15.6 \\
\hline Never & 4.7 \\
\hline
\end{tabular}

2. "How often during the day do you practice or compete outdoors?"

\begin{tabular}{|l|l|}
\hline Always & 10.9 \\
\hline Sometimes & 56.9 \\
\hline Rarely & 20.3 \\
\hline Never & 11.7
\end{tabular}

\section{3. "How frequently do you use tanning beds?"}

\begin{tabular}{|l|l|}
\hline Always & 7.3 \\
\hline Sometimes & 18.5 \\
\hline Rarely & 25 \\
\hline Never & 48.9 \\
\hline
\end{tabular}

4. "Use of sunscreen during daily activities"

\begin{tabular}{|l|l|}
\hline Always & 32.4 \\
\hline Sometimes & 20.3 \\
\hline Rarely & 15.9 \\
\hline Never & 31.2 \\
\hline
\end{tabular}

5. "Do you use sunscreen while sunbathing during holidays?"

Always

32.4

Sometimes

20.3

Rarely

15.9

Never

31.2

6. "Do you use SPF 30 or higher sunscreen"

\begin{tabular}{|l|l|}
\hline Always & 35.1 \\
\hline Sometimes & 20.9 \\
\hline Rarely & 16.8 \\
\hline Never & 24.2 \\
\hline 7. “Use of other sun protective measures*" \\
\hline Sun glasses & 26.2 \\
\hline Protective clothing & 25.6 \\
\hline Hats & 16.2 \\
\hline None of the above & 31.8 \\
\hline 8. "How often do you ask your physician to check your skifor
\end{tabular}

8. "How often do you ask your physician to check your skin for potential cancerous lesions?"

\begin{tabular}{|l|l|}
\hline Always & 12 \\
\hline Sometimes & 20.9 \\
\hline Rarely & 26.2 \\
\hline Never & 40.7 \\
\hline
\end{tabular}

9. "Do you examine your skin for potential cancerous lesions on your own?"

\begin{tabular}{|l|l|}
\hline Table 3. continued & 18.5 \\
\hline Always & 30.9 \\
\hline Sometimes & 20.3 \\
\hline Rarely & 30 \\
\hline Never & 's \\
\hline $\begin{array}{l}\text { 10. "If you are not using sun protective measures, what's } \\
\text { making you stay away from utilising them?*" }\end{array}$ \\
\hline Lazy/tired/no time & 54.6 \\
\hline Want to tan & 13.9 \\
\hline Embarrassed & 8.5 \\
\hline I don't need it & 23 \\
\hline *Indicates question has been excluded from the total behaviour score calculation. \\
\hline
\end{tabular}

\section{Discussion}

Light is an essential component of life. Various metabolic, endocrine, and physiological processes of life are dependent on sunlight. In addition to such advantages on life, sunlight also has a vast number of adverse effects on skin. These effects are more marked in countries like India which lie in tropical zone with high amount of sunlight exposure ${ }^{7}$. Photodermatoses are a group of disorders which occur due to UV light induced abnormal tissue responsiveness on the sun-exposed skin. They are classified as idiopathic photodermatoses, photodermatoses secondary to exogeneous agents or endogenous chemicals, photodermatoses due to defective DNA repair or photo aggravated dermatoses ${ }^{7,8}$. Various causes of idiopathic photodermatoses include solar urticaria, polymorphous light eruption, hydroa vacciniforme, actinic prurigo and chronic actinic dermatitis. Some photosensitisers may cause reactions such as phototoxic reaction, photo contact allergy and systemic photo allergy. Photodermatoses secondary to DNA repair defects are xeroderma pigmentosa, Bloom's syndrome, and Rothmund Thomson syndrome. Photo-aggravated dermatoses are lupus erythematosus, pemphigus erythematosus, atopic dermatitis, seborrheic dermatitis, acne vulgaris, rosacea, pemphigus erythematosus and bullous pemphigoid ${ }^{8}$.

The photodermatoses in India can be due to polymorphic light eruption, parthenium dermatitis with photo aggravation, phototoxic and photoallergic reactions due to various photosensitizing drugs and chemicals and nutritional deficiencies such as pellagra ${ }^{7}$.

Photoprotective measures constitute an essential component of all therapeutic regimens. These measures include protective clothing, shade, wide brimmed hat, sun glasses and effective sunscreens. The recent advances in cosmetology and dermatosurgery procedures have further enhanced the need to use sunscreens ${ }^{9}$.

In this study, the majority of the participants were males (53.1\%), followed by females (46.9\%), which is similar to another study which included male participants (51.5\%) followed by female participants $(48.5 \%)^{10}$ (Table 1). This is in contrast to another study which had $(63 \%)$ female participants followed by (37\%) male participants ${ }^{11}$. According to the findings in this study, undergraduate medical students have good knowledge on sun exposure and adverse effects of prolonged sun exposure on the skin. These findings are in contrast to other studies conducted on medical professionals, medical students, nursing students and survey conducted by American Academy of Dermatology 
Table 4. Knowledge, behaviour and awareness score by terms

\begin{tabular}{|c|c|c|c|c|}
\hline \multicolumn{2}{|l|}{ Term } & Knowledge & Behaviour & $\begin{array}{l}\text { Awareness } \\
(n=42)\end{array}$ \\
\hline \multirow{6}{*}{4.00} & Mean & 11.44 & 11.61 & 23.05 \\
\hline & $\mathrm{N}$ & 120 & 120 & 120 \\
\hline & $\begin{array}{l}\text { Standard } \\
\text { deviation }\end{array}$ & 3.183 & 4.646 & 5.784 \\
\hline & Minimum & 3 & 2 & 9 \\
\hline & Maximum & 20 & 22 & 35 \\
\hline & Median & 11.00 & 10.00 & 23.50 \\
\hline \multirow{6}{*}{7.00} & Mean & 11.93 & 11.38 & 23.31 \\
\hline & $\mathrm{N}$ & 100 & 100 & 100 \\
\hline & $\begin{array}{l}\text { Standard } \\
\text { deviation }\end{array}$ & 3.322 & 5.206 & 5.724 \\
\hline & Minimum & 4 & 0 & 13 \\
\hline & Maximum & 18 & 22 & 35 \\
\hline & Median & 12.00 & 12.00 & 24.00 \\
\hline \multirow{6}{*}{8.00} & Mean & 10.34 & 15.17 & 25.51 \\
\hline & $N$ & 35 & 35 & 35 \\
\hline & $\begin{array}{l}\text { Standard } \\
\text { deviation }\end{array}$ & 3.307 & 5.020 & 7.147 \\
\hline & Minimum & 3 & 7 & 13 \\
\hline & Maximum & 18 & 26 & 39 \\
\hline & Median & 10.00 & 15.00 & 25.00 \\
\hline \multirow{6}{*}{9.00} & Mean & 12.23 & 13.25 & 25.54 \\
\hline & N & 84 & 84 & 84 \\
\hline & $\begin{array}{l}\text { Standard } \\
\text { deviation }\end{array}$ & 3.359 & 4.718 & 6.891 \\
\hline & Minimum & 3 & 4 & 7 \\
\hline & Maximum & 19 & 24 & 40 \\
\hline & Median & 12.50 & 14.00 & 27.00 \\
\hline \multirow{6}{*}{ Total } & Mean & 11.67 & 12.32 & 24.00 \\
\hline & N & 339 & 339 & 339 \\
\hline & $\begin{array}{l}\text { Standard } \\
\text { deviation }\end{array}$ & 3.312 & 5.004 & 6.282 \\
\hline & Minimum & 3 & 0 & 7 \\
\hline & Maximum & 20 & 26 & 40 \\
\hline & Median & 11.00 & 12.00 & 24.00 \\
\hline
\end{tabular}

to assess the sun exposure risk and its harmful effects on the skin ${ }^{12-15}$. These findings are similar to a study conducted on medical students who had a good knowledge on this aspect ${ }^{16}$. Another study conducted on non-dermatologist physicians concluded that they had a correct knowledge on UV induced risk on skin and the appropriate protective measures to be used ${ }^{17}$.

In the study $63.1 \%$ of the participants strongly believed that use of sunscreens protects against skin cancer which was in accordance to another study where $44 \%$ of the participants strongly agreed that sunscreen use protects against skin cancer ${ }^{2}$. The study participants also had knowledge about need of frequent examination of skin

\begin{tabular}{|c|c|c|c|c|}
\hline \multicolumn{2}{|c|}{ Gender } & \multirow{2}{*}{$\begin{array}{l}\text { Knowledge } \\
11.89\end{array}$} & \multirow{2}{*}{\begin{tabular}{|l|} 
Behaviour \\
12.97 \\
\end{tabular}} & \multirow{2}{*}{$\begin{array}{l}\begin{array}{l}\text { Awareness } \\
(\mathbf{n}=\mathbf{4 2})\end{array} \\
24.89 \\
\end{array}$} \\
\hline \multirow{6}{*}{$F$} & Mean & & & \\
\hline & $\mathrm{N}$ & 159 & 159 & 159 \\
\hline & Standard deviation & 3.184 & 4.997 & 6.206 \\
\hline & Minimum & 3 & 3 & 7 \\
\hline & Maximum & 20 & 24 & 40 \\
\hline & Median & 12.00 & 13.00 & 25.00 \\
\hline \multirow{6}{*}{ M } & Mean & 11.47 & 11.74 & 23.21 \\
\hline & $N$ & 180 & 180 & 180 \\
\hline & Standard deviation & 3.418 & 4.953 & 6.260 \\
\hline & Minimum & 3 & 0 & 9 \\
\hline & Maximum & 19 & 26 & 39 \\
\hline & Median & 11.00 & 11.00 & 23.50 \\
\hline \multirow{6}{*}{ Total } & Mean & 11.67 & 12.32 & 24.00 \\
\hline & $\mathrm{N}$ & 339 & 339 & 339 \\
\hline & Standard deviation & 3.312 & 5.004 & 6.282 \\
\hline & Minimum & 3 & 0 & 7 \\
\hline & Maximum & 20 & 26 & 40 \\
\hline & Median & 11.00 & 12.00 & 24.00 \\
\hline
\end{tabular}

by dermatologist (84.9\%) and one's own self (78.5\%) to look for precancerous lesions which are in accordance to another study where $82.6 \%$ and $78.5 \%$ of individuals believed in doing the same ${ }^{6}$. The adverse effects of sun exposure including freckles and wrinkles was known in $63.1 \%$ and $60.1 \%$ of study participants which are similar to another study where the risk of freckles and wrinkles were known in $63.8 \%$ and $64 \%$ study participants ${ }^{6}$. The risk of skin cancer with sun exposure was quoted to be $58.4 \%$ according to the participants which is in contrast to another study where only $16.7 \%$ of general population were aware of this risk ${ }^{12}$. The sun being most harmful between 10 a.m. and 2 p.m. was known in $67.5 \%$ of study participants which was similar to another study where $76.8 \%$ of population knew the same. The majority of students in the study also had knowledge regarding the properties, quantity and frequency of application of sunscreen which was seen in $59.8 \%, 52.8 \%$ and $61.9 \%$ of population respectively which is similar to another study, in which these factors were known in $49.3 \%, 18.1 \%$ and $31.4 \%$ of the individuals of that study. Only $23 \%$ of the study participants knew about the meaning of SPF-30 that means an individual can stay additionally in the sun without burning, and $40.4 \%$ knew that SPF-30 offers minimal additional protection with larger cost disadvantage. These findings are similar to another study where only $22 \%$ of individuals were aware about this ${ }^{6}$. The risk of sunburn in childhood causing increased chances of skin cancer was known in $50.7 \%$ of these individuals which is slightly higher than another study where this risk was known in $31.4 \%$ of individuals only, and in contrast to another study where $97 \%$ of individuals knew about this ${ }^{12,13}$. The family history of skin cancer to increase the risk was known in $68.4 \%$ of study participants which were in accordance to other 
Table 6. Comparison of knowledge, behaviour and awareness of the participants between and within the groups ANOVA

\begin{tabular}{|c|c|c|c|c|c|c|}
\hline & & Sum of squares & df & Mean square & $\mathbf{F}$ & Sig. \\
\hline \multirow[b]{2}{*}{ Knowledge } & Between groups & 100,644 & 3 & 33,548 & 3,116 & 0.026 \\
\hline & Within groups & $3,606,690$ & 335 & 10,766 & - & - \\
\hline \multirow[b]{2}{*}{ Behaviour } & Between groups & 506,354 & 3 & 168,785 & 7,106 & 0.000 \\
\hline & Within groups & $7,956,873$ & 335 & 23,752 & - & - \\
\hline \multirow{3}{*}{ Awareness $(n=45)$} & Between groups & 434,271 & 3 & 144,757 & 3,758 & 0.011 \\
\hline & Within groups & $12,902,726$ & 335 & 38,516 & - & - \\
\hline & Total & $13,336,997$ & 338 & - & - & - \\
\hline
\end{tabular}

Table 7. Multiple linear regression model summary for the knowledge, awareness and behaviour variables with term as predictor

\begin{tabular}{|c|c|c|c|c|c|c|c|c|c|}
\hline \multirow{3}{*}{$\begin{array}{l}\text { Dependent } \\
\text { variable }\end{array}$} & \multirow{3}{*}{ Predictor } & \multicolumn{8}{|c|}{ Regression: Model summary } \\
\hline & & \multirow[t]{2}{*}{ Model } & \multirow[t]{2}{*}{$\mathbf{R}$} & \multirow[t]{2}{*}{ R square } & \multirow{2}{*}{$\begin{array}{l}\text { Adjusted R } \\
\text { square }\end{array}$} & \multirow{2}{*}{$\begin{array}{l}\text { Standard error of } \\
\text { the estimate }\end{array}$} & \multicolumn{3}{|c|}{ Change statistics } \\
\hline & & & & & & & $\begin{array}{l}\text { R square } \\
\text { change }\end{array}$ & F change & df1 \\
\hline Knowledge & Term & 1 & $0.057^{a}$ & 0.003 & 0.000 & 3.311 & 0.003 & 1,095 & 1 \\
\hline Behaviour & Term & 1 & $0.150^{\mathrm{a}}$ & 0.022 & 0.020 & 4.955 & 0.022 & 7,734 & 1 \\
\hline Awareness & Term & 1 & $0.152^{\mathrm{a}}$ & 0.023 & 0.020 & 6.218 & 0.023 & 7,991 & 1 \\
\hline
\end{tabular}

Table 8. Comparison of knowledge, awareness and behaviour variables between the participants with term as predictor

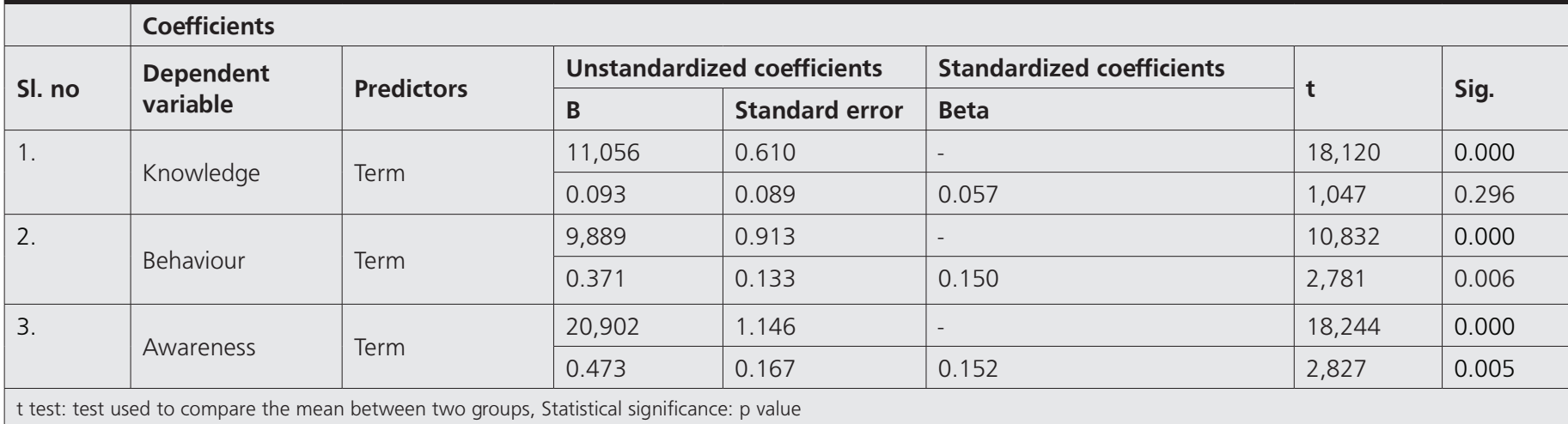

study where $63 \%$ of individuals knew about it ${ }^{17}$ (Table 2 ). Though these individuals had a good knowledge about sun protective measures, the behavioural aspects of these were relatively poor. Only $32 \%$ of the population compulsorily used sunscreen during daily activities and sunbathing which is in contrast to other studies on medical students where $70.7 \%$ and $77.9 \%$ of subjects used sunscreens ${ }^{13,16}$. Among these study participants, only $25 \%$ of them always seek shade which is relatively lower as compared to another study in which $61.5 \%$ seek shade ${ }^{13}$. Only $7.3 \%$ of the study population used tanning beds which is similar to another study where $10.8 \%$ used $i t^{13}$. In this study, only $35 \%$ of the population always used sunscreen with SPF-30 or more which is in contrast to other studies where $73 \%$ of population used sunscreen of SPF-30 and more. The other sun protective measures used included sunglasses (26.2\%), protective clothing (25.1\%) hats (16.2\%). However in another study, sunglasses was the most commonly used sunprotection measure $(83.4 \%)$, followed by protective clothes $(57.8 \%)$ and then sunscreens $(77.1 \%)^{18}$. This difference in percentage further highlights the lack of adequate behaviours in the study population. Majority of these individuals were lazy to use sun protective measures (54.6\%), wanted to tan (13.9\%), embarrassed (8.5\%) and were not in need of it $(23 \%)$. These findings are similar to another study where $47.2 \%$ individuals found it bothersome/lazy to use sunscreens, $36.6 \%$ individuals wanted to tan, $9.5 \%$ of these individuals were embarrassed to use sun protective measures and $26.2 \%$ of individuals did not feel the need to use any sun protective measures ${ }^{18}$ (Table 3 ). This study highlights that the sun protective behaviour was not parallel to the 
knowledge possessed by these individuals. The mean behaviour score of the study population was $12.32 \pm 5.004$ with a maximum score of 26 (Table 4). These findings are similar to other studies in which individuals of study population had a low behaviour score ${ }^{14,19}$. Statistically significant differences was seen in the mean awareness scores with p-value of 0.0138 with a higher mean awareness score of 24.89 in females as compared to males in whom a mean score of 23.21 (Table 5) was seen which is in contrast to other studies in which gender did not have an influence on the awareness score ${ }^{20,21}$. Statistically significant differences in knowledge behaviour and awareness scores were seen in this study among the students of the terms and between the terms which were not seen in other studies where semesters/terms failed to have an impact on these scores (Table 6,8) ${ }^{20,21}$.

\section{Study Limitations}

Limited time frame of study, limiting population size.

\section{Conclusion}

Photoprotection protects individuals from cumulative and hazardous effects of the sun. Though sunscreens constitute the most important component of photoprotection, this can also be accomplished by protective clothing, seeking shade and other behavioural changes. The reinforcement of sunscreen application by the physician can improve the patient's compliance and its outcome ${ }^{22}$. In addition, lifestyle changes and behavioral changes can be achieved through these studies ${ }^{23}$.

\section{Ethics}

Ethics Committee Approval: The Sri. Devaraj Urs Medical College Institutional Ethics Committee approval was obtained (approval number: SDUM/KLR/IEC/94.2018-19, date: 23.05.2018).

Informed Consent: Written informed consent was obtained from all participating patients.

Peer-review: Externally peer-reviewed.

\section{Authorship Contributions}

Surgical and Medical Practices: S.M.G., R.T.S., S.K.K., P.P., Concept: S.M.G., R.T.S., S.K.K., P.P., Design: S.M.G., R.T.S., S.K.K., P.P., Data Collection or Processing: S.M.G., R.T.S., S.K.K., P.P., Analysis or Interpretation: S.M.G., R.T.S., S.K.K., P.P., Literature Search: S.M.G., R.T.S., S.K.K., P.P., Writing: S.M.G., R.T.S., S.K.K., P.P.

Conflict of Interest: No conflict of interest was declared by the authors.

Financial Disclosure: The authors declared that this study has received no financial support.

\section{References}

1. Gavelan ET, Ramos W, Sialer MDC, Anduaga ES, Saldana LS: Knowledge, attitudes and practices about sun exposure and photoprotection in outpatients attending dermatology clinics at four hospitals in Lima, Peru. An Bras Dermatol 2011;86:1122-8.

2. Agarwal SB, Godse K, Patil S, Nadkarni N: Knowledge and attitude of general population toward effects of sun exposure and use of sunscreens.
Indian J Dermatol 2018;63:285-91.

3. Khalid MA, Ghamadi AS, Abdulla AZ, Qahatani AL: Knowledge, attitudes and practices of the general public toward sun exposure and protection: A national survey in Saudi Arabia. Saudi Pharm J 2015;24:652-7.

4. Mutairi NA, Issa BI, Nair V: Photoprotection and vitamin D status: A study on awareness, knowledge and attitude towards sun protection in general population from Kuwait, and its relation with vitamin D levels. Indian J Dermatol Venereol Leprol 2012;78:342-9.

5. Marks R, Knight KR, Thompson SC: The Effect of Regular Sunscreen Use on Vitamin D Levels in an Australian Population. Arch Dermatol 1995;131:41521.

6. Alzahrani NA, Fathi TT, Mortada HH, et al: Awareness, knowledge and behavior of medical personnel regarding skin cancer, sun-related hazards and sunscreen utilization at King Abdulaziz University Hospital, Jeddah. Int J Res Dermatol 2018;4:105-14.

7. Srinivas $C R$, Sekar CS, Jayashree R: Photodermatoses in India. Indian J Dermatol Venereol Leprol 2012;78 (Suppl 1):S1-8.

8. Bylaite M, Grigaitiene J, Lapinskaite GS: Photodermatoses: classification, evaluation and management. Br J Dermatol 2009;S3:61-8.

9. Rai R, Shanmuga SC, Srinivas CR: Update on photoprotection. Indian J Dermatol 2012;57:335-42.

10. AlRobaee AA: Awareness to sun exposure and use of sunscreen by the general population. Bosn J Basic Med Sci 2010;10:314-8.

11. Bazarbashi S, Al Eid H, Minguet J: Cancer Incidence in Saudi Arabia: 2012 Data from the Saudi Cancer Registry. Asian Pac J Caner Prev 2017;18:243742.

12. Alamri F, Saeedi MY, Alharbi M, Ibrahim AM, Kassim KA: Skin cancer and its correlates: a study of knowledge and preventive behavior in Riyadh. Cancer Res Clin Oncol 2016;5:12-9.

13. Isvy A, Beauhcet A, Salag P, Mahe E: Medical students and sun prevention: knowledge and behaviours in France. I Eur Acad Dermatol Venereol 2013;27:e247-51.

14. Yilmaz $M$, Yavuz $B$, Subasi $M$, et al: Skin cancer knowledge and skin protection among nursing students. Jpn J Nurs Sci 2015;12:69-78.

15. Miller DR, Geller AC, Koh HK: Survey of knowledge of and awareness about melanoma - United States. J Am Acad Dermatol 1995;1-3.

16. Suppa M, Cazzaniga S, Fargnoli MC, Naldi L, Peris K: Knowledge, perceptions and behaviours about skin cancer and sun protection among secondary school students from Central Italy. J Eur Acad Dermatol Venereol 2013;27:571-9.

17. Thomas M, Rioual E, Adamski H, Roguedas AM, Misery L, Michel M: Physicians involved in the care of patients with high risk of skin cancer should be trained regarding sun protection measures: evidence from a cross sectional study. J Eur Acad Dermatol Venereol 2011;25:19-23.

18. Nikolaou V, Stratigos AJ, Antoniou C, et al: Sun exposure behavior and protection practices in a Mediterranean population: a questionnaire-based study. Photodermatol Photo 2009;25:132-7.

19. Hobbs C, Nahar VK, Ford MA, Bass MA, Brodell RT: Skin cancer knowledge, attitudes, and behaviors in collegiate athletes. J Skin Cancer 2014;2014:248198.

20. Kristjansson S, Ullen $H$, Helgason HR: The importance of assessing the readiness to change sun-protection behaviours: a population-based study. Eur J Cancer 2004;40:2773-80

21. Cinar ND, Cinar S, Karakoc A, Ucar F: Knowledge, attitudes and behaviors concerning sun protection/skin cancer among adults in Turkey. Pak J Med Sci 2009;25:108-12.

22. Palm MD, Odonoghue MN: Update on photoprotection. Dermatol Ther 2007;20:360-76.

23. Anand $P$, Kunnumakkara $A B$, Sundaram $C$, et al: Cancer is a preventable disease that requires major lifestyle changes. Pharm Res 2009;25:2097-112. 